\title{
Emission of Gases During Composting of Solid Waste
}

DOI: 10.15255/KUI.2016.050

KUI-34/2017

Original scientific paper

Received December 9, 2016

Accepted February 20, 2017

This work is licensed under

Creative Commons Attribution 4.0 International Licens

\author{
D. Kučić* and F. Briški
}

University of Zagreb, Faculty of Chemical Engineering and Technology,

Department of Industrial Ecology, Marulićev trg 19, 10000 Zagreb, Croatia

\begin{abstract}
\| Abstract
Composting is a biochemical process converting organic components into stable compost with release of heat, water, $\mathrm{CO}_{2}$ and $\mathrm{NH}_{3}$. The objective of this work was to determine the amount of $\mathrm{CO}_{2}$ and $\mathrm{NH}_{3}$ in the exhaust gases during composting of tobacco waste (TW) and mixture of tobacco and grape waste (TCW). The cumulative evolved $\mathrm{CO}_{2}$ during 21 days of composting of TW and TCW, per mass of volatile matter, was $94.01 \mathrm{~g} \mathrm{~kg}^{-1}$ and $208.18 \mathrm{~g} \mathrm{~kg}^{-1}$, respectively, and cumulative evolved $\mathrm{NH}_{3}$ during composting of TW and TGW, per mass of volatile matter, was $504.81 \mathrm{mg} \mathrm{kg}^{-1}$ and $122.45 \mathrm{mg} \mathrm{kg}^{-1}$, respectively.
\end{abstract}

\section{\| Keywords}

Composting, agro-industrial waste, adiabatic closed reactor, ammonia emission, carbon dioxide emission

\section{Introduction}

Industrial wastes include solid or liquid mass containing considerable amounts of organic matter. Tobacco and grape waste are classified as industrial wastes of organic origin, which are generated in different processes of the tobacco and cigarette production cycle and production of wine, respectively. ${ }^{1,2}$ Composting is an environmentally friendly and effective technology for treatment or management of organic wastes, which end-product is suitable for use as soil conditioner. ${ }^{3}$ It is a biological treatment in which aerobic mesophilic and thermophilic microorganisms transform the biodegradable organic matter into $\mathrm{CO}_{2}$, $\mathrm{NH}_{3}, \mathrm{H}_{2} \mathrm{O}$ and a stable organic matter-compost. ${ }^{4}$ Carbon dioxide is identified as a biogenic gas, because $\mathrm{CO}_{2}$ is a measure of microbial respiration, and ammonia is generated as a product of microbial transformation of organic nitrogen. ${ }^{5}$ Composting is used widely, but the hazardous and malodour emissions from composting plants represent a key environmental issue, particularly in highly populated countries. ${ }^{6,7}$ Carbon dioxide $\left(\mathrm{CO}_{2}\right)$ and ammonia $\left(\mathrm{NH}_{3}\right)$ are two major polluting gases which evolve during composting of tobacco and mixture of tobacco and grape waste. $\mathrm{CO}_{2}$ is a greenhouse gas with a large impact on climate change, while ammonia is one of the main compounds responsible for generation of offensive odours and atmospheric pollution when composting organic waste with high nitrogen content. ${ }^{8}$ Also, ammonia is a toxic and corrosive air pollutant responsible for acidification of rain and formation of aerosols. ${ }^{9,10}$ Several factors such as $\mathrm{C} / \mathrm{N}$ ratio, temperature, mixing and turning, and aeration rate can influence the volatilization of ammonia during composting. Composting

${ }^{*}$ Corresponding author: Dajana Kučić, PhD

e-mail: dkucic@fkit.hr of nitrogen-rich wastes can be associated with substantial gaseous nitrogen losses. ${ }^{11}$ Therefore, initial $\mathrm{C} / \mathrm{N}$ ratio of tobacco waste has been adjusted to the proper range by adding grape waste with high carbon content, since greater nitrogen assimilation can facilitate less ammonia loss and enhance retention of nitrogen in the final compost product. $^{12}$

The aim of this work was to determine the concentration of carbon dioxide $\left(\mathrm{CO}_{2}\right)$ and ammonia $\left(\mathrm{NH}_{3}\right)$ in the exhaust gases during composting of tobacco waste (TW) and the mixture of tobacco and grape waste (TGW) in a laboratory-scale column reactor.

\section{Experimental}

\subsection{Materials}

In this work, two different substrates were used, tobacco waste (TW) and a mixture of tobacco and grape waste (TGW). The tobacco waste was generated during tobacco production in the tobacco factory TDR, Rovinj, Croatia. The TW product was composed of very fine powdery residues, leaf stalks and wet leaf parts with average moisture content of about $75 \%$. The TW was dried at room temperature until the moisture content was $10 \%$ and then stored in cartons. This TW was used in the experiments. The grape waste was generated from wine production from the Plesivica hills in the western part of Croatia. In order to avoid any kind of degradation, fresh grape waste was kept in a freezer at $-18{ }^{\circ} \mathrm{C}$ until it was used for the experiments. Table 1 presents the main characteristics of the initial composting mixture. 
Table 1 - Characteristics of the initial tobacco waste, grape waste, and mixture of tobacco and grape waste

Tablica 1 - Karakterizacija duhanskog otpada, otpada od grožđa i mješavine duhanskog otpada i otpada od grožđa

\begin{tabular}{l|c|c|c}
\hline & Tobacco waste & Grape waste & $\begin{array}{c}\text { Tobacco and } \\
\text { grape waste }\end{array}$ \\
\hline moisture $/ \%$ & 9 & 60 & 61 \\
dry matter $/ \%$ & 91 & 40 & 39 \\
volatile matter $/ \%$ & 78 & 93 & 86 \\
C/N mass ratio & $21 / 1$ & $48 / 1$ & $35 / 1$ \\
$\mathrm{pH}$ & 6.5 & 4.5 & 5.6 \\
\hline
\end{tabular}

\subsection{Composting experiments}

The composting experiments of TW and TGW were conducted in a closed, thermally insulated column reactor with effective volume of $10 \mathrm{dm}^{3}$, Fig. 1 . The reactor was operated at an airflow rate of $0.66 \mathrm{dm}^{3} \mathrm{~min}^{-1} \mathrm{~kg}^{-1}$ per volatile mater (VM) and the temperature was monitored by thermocouples connected to the data logger during the 21 days of composting period. The composting mixture of TGW was prepared by mixing of grape waste (GW) and tobacco waste (TW) in the ratio of GW: TW $=55: 45$ (dry weight). This ratio was chosen based on initial $\mathrm{C} / \mathrm{N}$ ratio of tobacco and grape waste. The moisture content of the substrate (TW and TGW) was set to about $60 \%$ by adding water, and the $4.0 \mathrm{~kg}$ of mixture was put into the reactor from the top. To ensure permanent air humidity at the reactor's inlet, the air was saturated with moisture prior to entering the reactor by passing through a Drechsel bottle. After leaving the reactor, the hot spent air was allowed to cool naturally and the condensate was collected in the graduated cylinder.

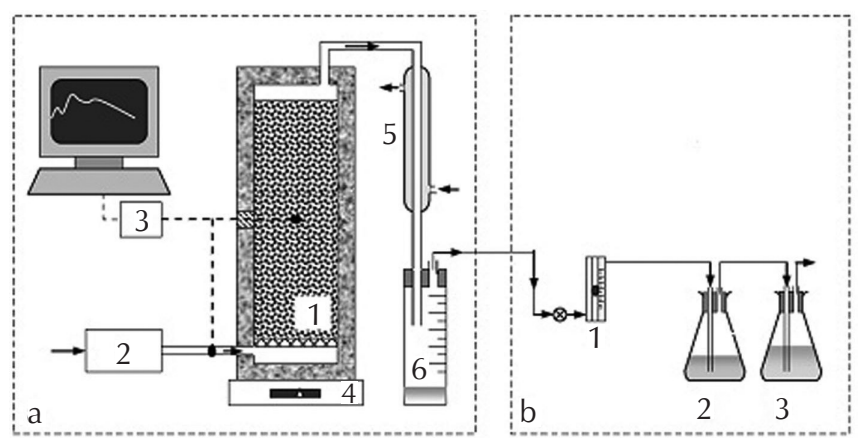

Fig. 1 - Schematic diagram of the composting process (a) 1 composting reactor, 2 - compressor and airflow regulation, 3 - temperature data acquisition, 4 - scale, 5 - condenser, 6 - graduated cylinder; and gas absorption and analysis (b) 1 - flowmeter, $2-\mathrm{H}_{3} \mathrm{BO}_{3}, 4 \%, 3-$ $\mathrm{NaOH}, 1 \mathrm{~mol} \mathrm{dm}^{-3}$

Slika 1 - Shematski prikaz procesa kompostiranja (a) 1 - reaktor, 2 - kompresor i rotametar, 3 - zapis temperature, 4 - vaga, 5 - kondenzator, 6 - graduirani cilindar, i apsorpcija plinova (b) 1 - rotametar, $2-\mathrm{H}_{3} \mathrm{BO}_{3}, 4 \%, 3$ $-\mathrm{NaOH}, 1 \mathrm{~mol} \mathrm{dm}^{-3}$

\subsection{Analytical methods}

The composting samples, taken periodically from the reactor, were tested for $\mathrm{pH}$, moisture, volatile solid contents, carbon and nitrogen $(\mathrm{C} / \mathrm{N})$ ratio, and microbial diversity. The moisture content and volatile solids in the composting mass were determined gravimetrically, ${ }^{13} \mathrm{pH}$ was measured with $\mathrm{pH}$ meter, and the total nitrogen content using Kjeldahl method. ${ }^{13}$ The exhaust gases, ammonium and carbon dioxide, were absorbed into $4 \%$ boric acid ${ }^{14}$ and in $1 \mathrm{~mol} \mathrm{dm}^{-3}$ sodium hydroxide, ${ }^{15}$ respectively, and determined titrimetrically. Colony-forming units (CFU) of mesophilic and thermophilic bacteria and fungi were determined on the general-purpose media by the pour plate method. ${ }^{16}$ The incubation time was 24-48 $\mathrm{h}$ for mesophilic and thermophilic bacteria and $72 \mathrm{~h}$ for mesophilic and thermophilic fungi. The temperature was $37^{\circ} \mathrm{C}$ and $28{ }^{\circ} \mathrm{C}$ for mesophilic bacteria and fungi, and $50{ }^{\circ} \mathrm{C}$ for thermophilic bacteria and fungi. The results were expressed as CFU per g of dry matter. ${ }^{16}$

\section{Results and discussion}

\subsection{Temperature profile and growth of microorganisms}

Temperature is one of the most important parameters for maintaining the efficiency of the composting process. Biological activity is an indicator of biodegradation of organic matter because aerobic microorganisms produce heat in composting mass. ${ }^{14}$ The temperature undergoes considerable changes due to a calorific effect, resulting from oxidative cleavage of covalent bonds in the substances during composting. ${ }^{17}$ All composting processes are known to go through three stages: mesophilic, thermophilic, and cooling. Stentiford ${ }^{18}$ suggested that temperatures higher than $55{ }^{\circ} \mathrm{C}$ maximized sanitation, those between 45 and $55^{\circ} \mathrm{C}$ maximized the biodegradation rates, and those between 35 and $40{ }^{\circ} \mathrm{C}$ maximized microbial diversity in the composting process. The initial temperature of the composting mass of TW was $25^{\circ} \mathrm{C}$ and after 48 hours rapidly increased to $56{ }^{\circ} \mathrm{C}$. The third day of composting, the temperature dropped to $39{ }^{\circ} \mathrm{C}$, and the day after increased again to a peak of $44{ }^{\circ} \mathrm{C}$. Afterward, the composting mass started to cool until the compost and ambient temperatures levelled (Fig. 2).

In contrast, the temperature of the TGW composting mass at beginning of the process was $22{ }^{\circ} \mathrm{C}$, and after 4 days started to increase until day 9 . After 10 days of composting, the composting mass started to cool until compost and ambient temperature levelled (Fig. 3). In the case of TCW, the thermophilic phase was longer (Fig. 3). This was probably due to the combination of organic compounds found in this mixture, in which organic matter is mainly composed of easily degradable compounds. The mesophilic stage usually starts at the beginning of a process during which the microorganisms undergo adaptation and proliferate. ${ }^{17}$ The temperature levels in the composting mass tended to increase and reached $50-60{ }^{\circ} \mathrm{C}$ due to the energy released from the biochemical reactions of the mesophilic micro- 


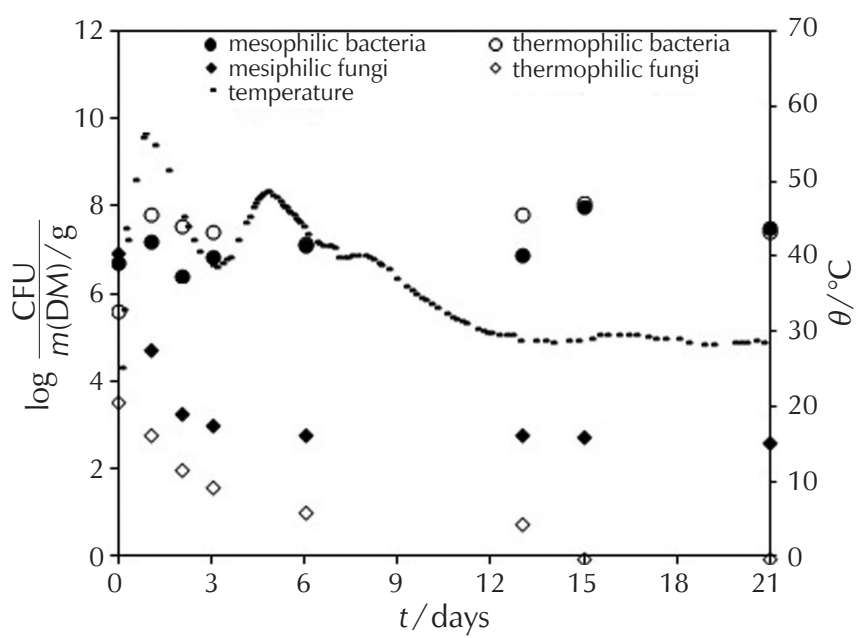

Fig. 2 - Temperature variations in composting mass of tobacco waste and growth of microorganisms during 21 days of composting

Slika 2 - Promjena temperature i ukupnog broja mezofilnih i termofilnih mikroorganizama tijekom 21 dana kompostiranja duhanskog otpada

organisms. Increased temperature enabled the growth of thermophilic microorganisms and their activity.

In this phase, metabolic heat started to decrease as a result of biodegradation of macromolecules that uses a large amount of energy, and the temperature started to drop. ${ }^{1}$ This enabled the regrowth of mesophilic microorganisms. The secondary temperature peak that occurred was possibly a result of delayed microbial growth (recovered mesophilic microbial population) in the outer portions of the composting mixture, either due to the water leached from the top, or lower heat removal rate due to the predominance of low constant aeration rate, or both. ${ }^{19}$ At the end of the experiment, the organic components of the waste underwent their final degradation, and the temperature curve was typical of a laboratory composting process and indicated that the system was operating satisfactorily.

The growth of both the mesophilic $\left(20-45{ }^{\circ} \mathrm{C}\right)$ and thermophilic $\left(45-70{ }^{\circ} \mathrm{C}\right)$ bacteria and fungi, at various stages of the composting process of TW and TGW, was determined (Figs. 2 and 3). The microbial species involved in the degradation of the substrate and their number changed with the changes in reactor temperature. During the first day of TW composting, the number of mesophilic bacteria increased from $5.49 \cdot 10^{6}$ to $1.35 \cdot 10^{7}$, and at day fifteen up to $9.83 \cdot 10^{7}$. After that, their number slowly started to decrease. The exponential growth $\left(4.17 \cdot 10^{5}\right.$ to $\left.4.23 \cdot 10^{7}\right)$ of thermophilic bacteria (TW) started after the first day because the temperature was about $50{ }^{\circ} \mathrm{C}$, and until the end of composting their number had not increased further. The number of mesophilic bacteria in the composting mixture of TGW was $8.5 \cdot 10^{7}$, and after 7 days increased to $1.2 \cdot 10^{9}$ and remained at this level until the end of the

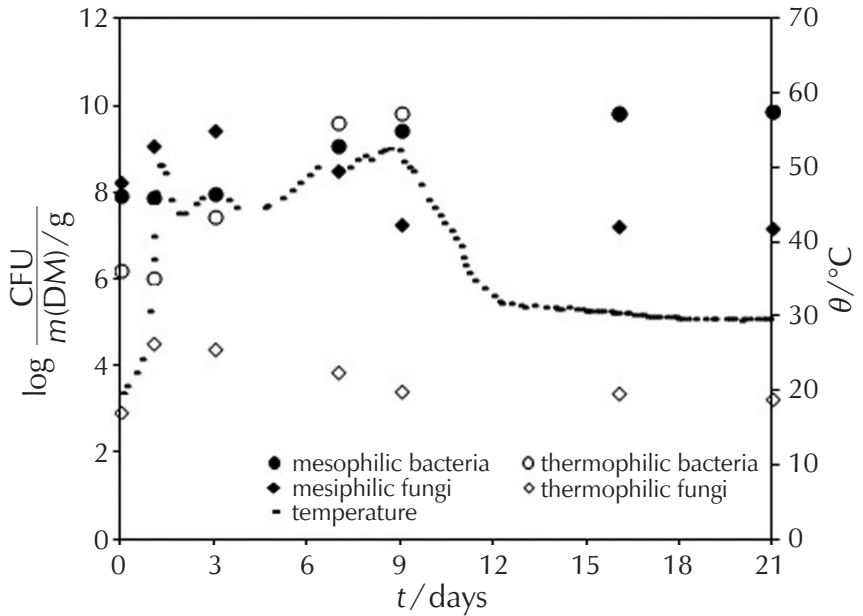

Fig. 3 - Temperature variations in composting mass of mixture of tobacco and grape waste and growth of microorganisms during 21 days of composting

Slika 3 - Promjena temperature i ukupnog broja mezofilnih i termofilnih mikroorganizama tijekom 21 dana kompostiranja duhanskog otpada i otpada od grožđa

process. The growth of thermophilic bacteria started to increase after the third day $\left(1.7 \cdot 10^{6}\right.$ to $\left.3.0 \cdot 10^{7}\right)$. Bacteria are mostly responsible for the initial phase of the composting process because they consume the available soluble nutrients and produce metabolic heat. ${ }^{20}$ From the start of experiment TW, the number of mesophilic $\left(5.48 \cdot 10^{4}\right)$ and thermophilic $\left(3.43 \cdot 10^{3}\right)$ fungi decreased, and until the end of the process, only mesophilic fungi were detected $\left(6.31 \cdot 10^{2}\right)$. In contrast, the mesophilic and termophilic fungi were present throughout the TCW composting period (Fig. 3). From these results, it can be seen that the number of mesophilic and thermophilic fungi in the composting mass of TGW was higher than in the composting mass of TW because grape waste initially contained a high concentration of simple organic compounds such as fruit sugar. Further, the initial $\mathrm{pH}$ values of TW and TGW were 6.5 and 5.3, respectively, which was adequate for fungal growth (Table 1). Fungi are generally more tolerant to acidic environments and less tolerant to temperatures above $35-40{ }^{\circ} \mathrm{C}$ than bacteria, and therefore they are an important group in the early phase of composting. ${ }^{21}$

\subsection{Emission of carbon dioxide and ammonia}

Carbon dioxide and ammonia were the main gases released during composting of tobacco waste and mixture of tobacco and grape waste. The dynamics of $\mathrm{CO}_{2}$ release in the compost reactor is highly influenced by the temperature regime. The higher $\mathrm{CO}_{2}$ production occurred in the first part of the process characterized by high temperatures and intense biodegradation of organic fraction of tobacco waste and mixture of tobacco and grape waste (Fig. 4 (a) and (b)). 
It can be seen from Fig. 4 that after 6 (TW) and 10 (TGW) days, the concentration of carbon dioxide started to decrease until the end of the process. The variation of $\mathrm{CO}_{2}$ concentration during that period is in correlation with bacterial activity and reaction temperature (Figs. 2-4). The cumulative evolved $\mathrm{CO}_{2}$ per mass of $\mathrm{VM}$ during 21 days of composting of TW and TGW was $94.01 \mathrm{~g} \mathrm{~kg}^{-1}$ and $208.18 \mathrm{~g} \mathrm{~kg}^{-1}$, respectively.

Ammonia emissions have been proposed in some works as an indicator of the biological activity in composting materials with high nitrogen content. ${ }^{8}$ Tobacco waste has high nitrogen content and therefore a low $\mathrm{C} / \mathrm{N}$ ratio, while the mixture of tobacco and grape waste has optimal $\mathrm{C} / \mathrm{N}$ ratio. It is known that temperature, $\mathrm{pH}$ value, and $\mathrm{C} / \mathrm{N}$ ratio are the main factors influencing ammonia emissions from the composting mass (Figs. 5 and 6). High temperature and
$\mathrm{pH}$ value affects ammonia volatilization, thus non-volatile ammonium ions are converted to the volatile ammonia form. ${ }^{8}$ Also, it is well known that $\mathrm{NH}_{3}$ emission strongly depends on the $\mathrm{pH}$ of the composting materials, and that $\mathrm{NH}_{3}$ evolves into exhaust gas when the $\mathrm{pH}$ of the composting material exceeds approximately $8 .^{9}$ The $\mathrm{pH}$ values of composting mass ordinarily vary from weakly acidic to neutral. The optimum $\mathrm{pH}$ value of composting is between 5.5 and 8.0. ${ }^{3}$ During the biodegradation of nitrogen-containing compounds, nitrogen is transformed to ammonium ions and the composting mass becomes alkaline, which is closely related to the activity of bacteria participating in the process of compost formation. ${ }^{17}$ The $\mathrm{pH}$ value of the composting mass of TW and TGW at the beginning of process was 6.5 and 5.3, and at the end of process 9.2 and 8.8, respectively (Fig. 5).
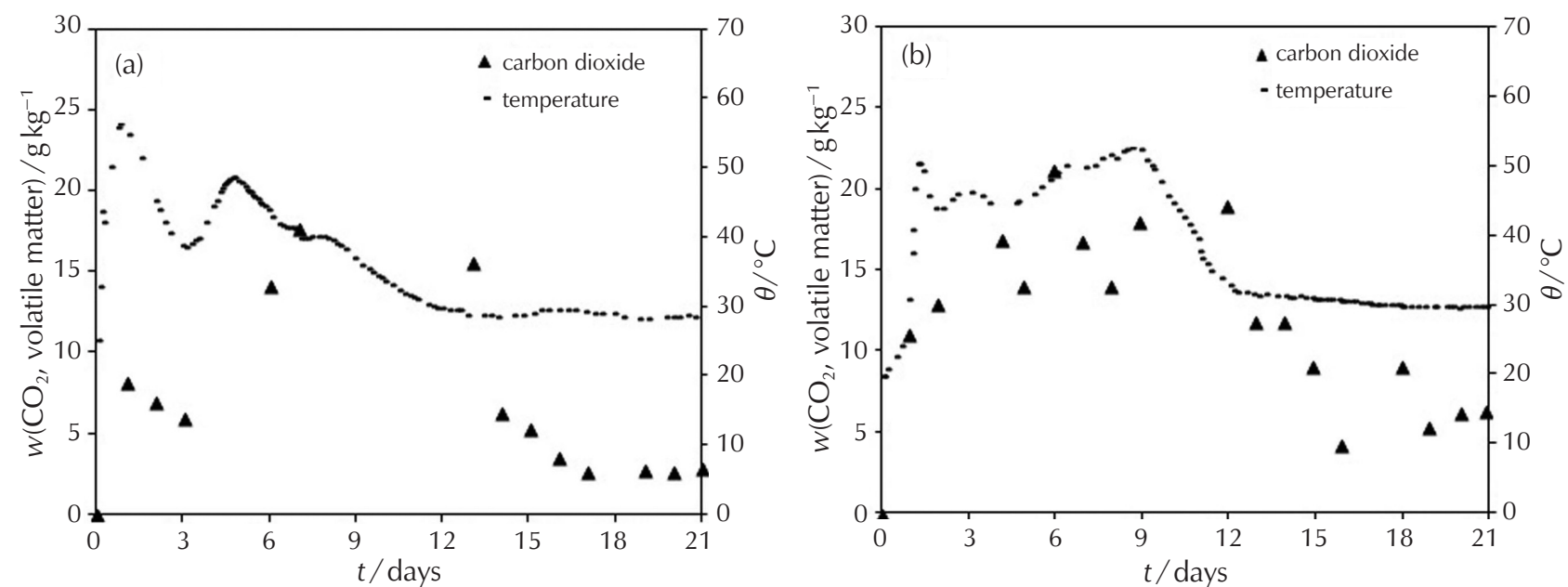

Fig. 4 - Evolution of carbon dioxide versus temperature during composting of tobacco waste (a), and mixture of tobacco and grape waste (b)

Slika 4 - Promjena mase $\mathrm{CO}_{2}$ i temperature tijekom 21 dana kompostiranja duhanskog otpada (a) i mješavine duhanskog otpada i otpada od grožđa (b)
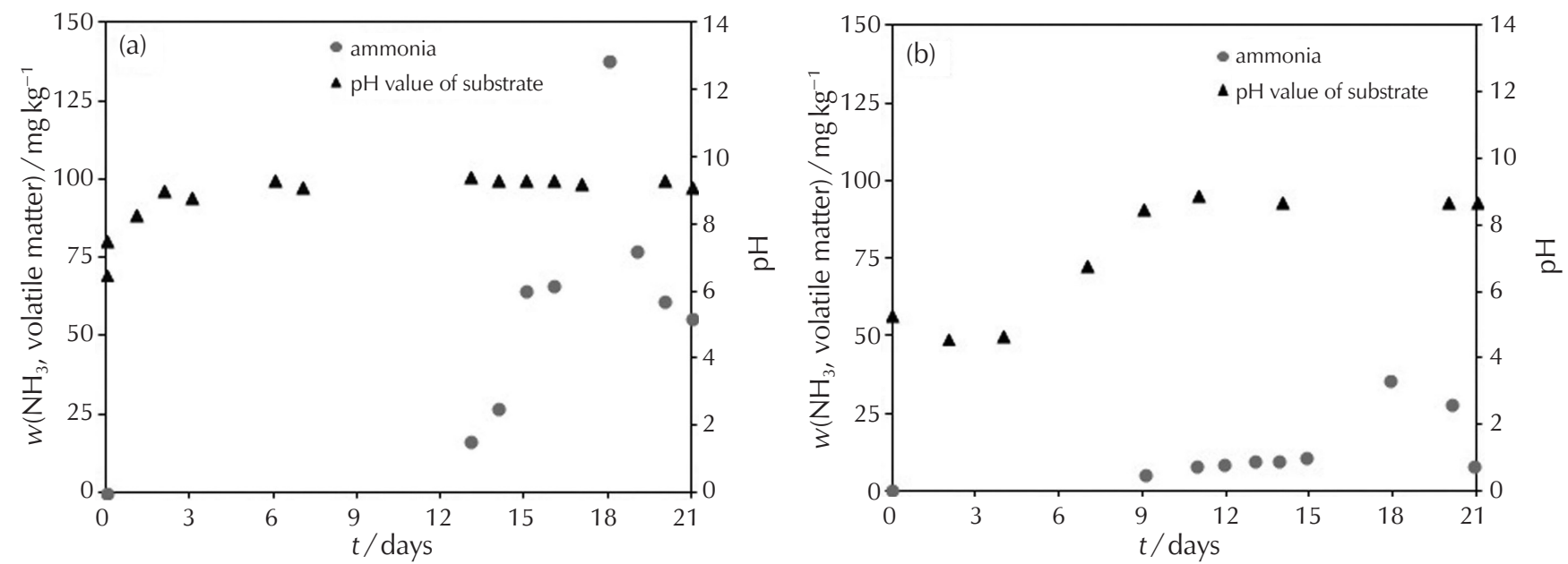

Fig. 5 - Mass of ammonia in exhaust air versus $\mathrm{pH}$ of substrate during composting of tobacco waste (a), and mixture of tobacco and grape waste (b)

Slika 5 - Promjena mase $\mathrm{NH}_{3}$ i pH supstrata tijekom 21 dana kompostiranja duhanskog otpada (a) i mješavine duhanskog otpada i otpada od grožđa $(b)$ 
From Fig. 5 (b) it can be seen that $\mathrm{pH}$ value of TGW dropped to acidic range $(\mathrm{pH}=4.6)$ because of production of organic acids. ${ }^{3}$ Afterward, the $\mathrm{pH}$ value started to increase to $\mathrm{pH}=8.6-9.0$ and thus remained until the end of the process. The increase in $\mathrm{pH}$ value during the composting process is due to the production of ammonium ions as a result of the ammonification process. ${ }^{23}$ During the first 10 days of composting, the concentration of ammonia in exhaust air was low. As the $\mathrm{pH}$ value increased, the concentration of ammonia in exhaust air also increased, and when the $\mathrm{pH}$ was approximately 9 , the highest concentration of ammonia was detected (on day 19 for TW and day 18 for TGW). Further, the concentrations of ammonia in exhaust air (VM) were lower in composting mass of TGW (122.456 $\left.\mathrm{mg} \mathrm{kg}^{-1}\right)$ than in composting mass of TW $\left(504.81 \mathrm{mg} \mathrm{kg}^{-1}\right)$ due to the lower nitrogen content in TGW. Furthermore, from Fig. 6 it can be seen that the concentration of ammonia in condensate during composting of TW (Fig. 6 (a)) is also much higher than during composting of TGW (Fig. 6 (b)). The cumulative evolved ammonia in condensate of TW was $11.505 \mathrm{mg} \mathrm{dm}^{-3}$ and of TGW $1.604 \mathrm{mg} \mathrm{dm}^{-3}$.

\section{$3.3 \mathrm{C} / \mathrm{N}$ ratio and conversion of substrate during composting of different solid waste}

The $\mathrm{C} / \mathrm{N}$ ratio has frequently been used to describe the course of organic waste degradation and it is widely accepted that a high substrate $\mathrm{C} / \mathrm{N}$ ratio implies a low mineralization rate due to $\mathrm{N}$ deficiency. ${ }^{25}$ The initial carbon and nitrogen ratio is the most important index of compost quality. Based on the nutritional requirements of the microbes that are active in composting, $\mathrm{C} / \mathrm{N}$ ratio of the organic matter should be in the order of 25-35 parts carbon to 1 part nitrogen; a declination from this ratio leads to a slow composting process. ${ }^{1}$ The initial $\mathrm{C} / \mathrm{N}$ ratio of tobacco waste and mixture of tobacco and grape waste was 21 and 35, respectively. It gradually decreased with increasing conversion of volatile solids, expressed as degradation of organic matter in waste solid (Fig. 7). At the beginning of the process, degradation of organic matter was faster in TW because in TGW the $\mathrm{pH}$ value dropped to 4 which inhibits growth of bacteria as the main microorganisms for degradation of organic matter. After 7 days of composting when $\mathrm{pH}$ value increased, the degradation rate in TCW was faster because grape contains sugars that are easily degradable components and are not toxic to microorganisms like nicotine. The most intense degradation was evident in the first 13 days, i.e. in the first half of the composting process, when conversion in TW and TGW was approximately $35 \%$ and $45 \%$, respectively. The nitrogen as ammonium ions remained in the composting mass until day 15 when the volatilization of ammonium ions started (Fig. 5). At the end of composting, the obtained conversion of tobacco waste and mixture of tobacco and grape waste was $47 \%$ and $55 \%$, while $\mathrm{C} / \mathrm{N}$ ratio 10 and 23 , respectively.

The biodegradation of TW and TGW can be expressed through mass balance:

$$
\begin{gathered}
1284 \mathrm{gDM}+248 \mathrm{gO}_{2} \\
\Rightarrow \\
117.5 \mathrm{gCO}_{2}+330 \mathrm{~g}_{2} \mathrm{O}+1075 \text { gdry compost }+0.505 \mathrm{gNH}_{3} \\
1500 \mathrm{gDM}+471 \mathrm{gO}_{2} \\
\Rightarrow \\
281 \mathrm{gCO}_{2}+464 \mathrm{~g} \mathrm{H}_{2} \mathrm{O}+1100 \text { gdry compost }+0.122 \mathrm{gNH}_{3}
\end{gathered}
$$
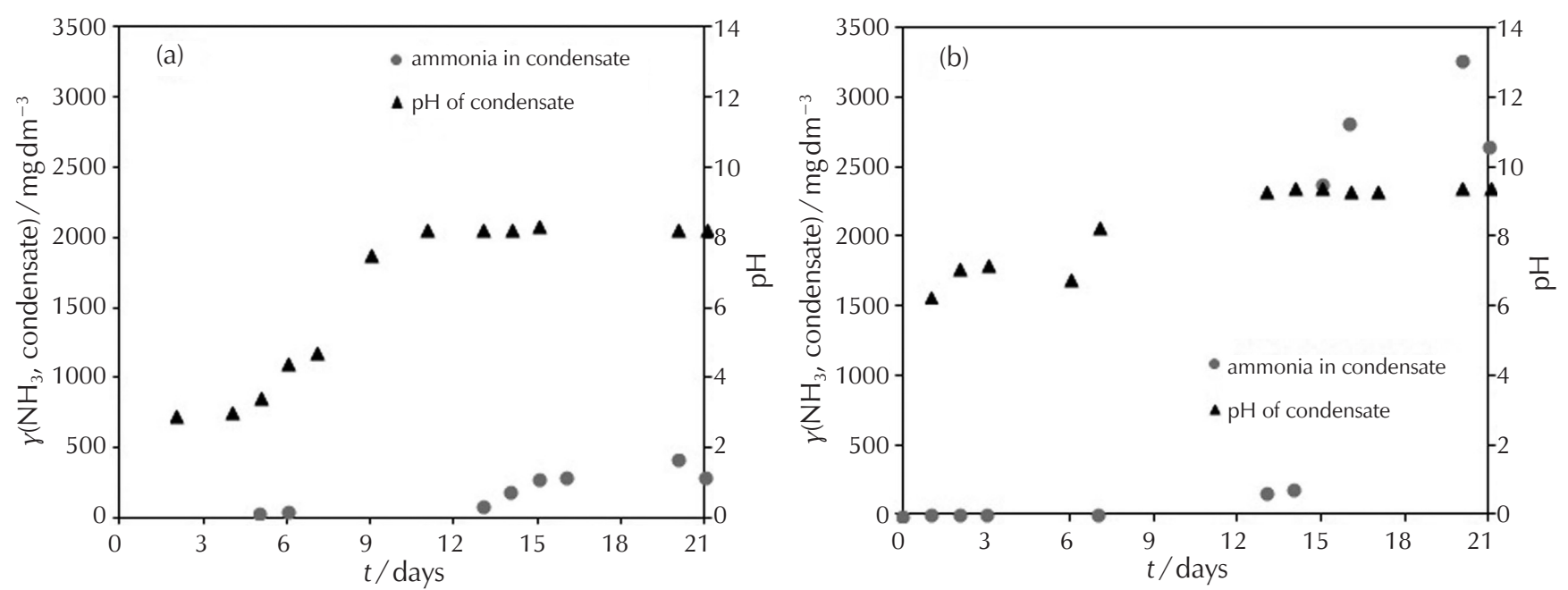

Fig. 6 - Concentration of ammonia in condensate versus pH of condensate during composting of TGW (a) and TW (b)

Slika 6 - Promjena koncentracije $\mathrm{NH}_{3}$ i pH kondenzata tijekom 21 dana kompostiranja mješavine duhanskog otpada i otpada od grožđa (a) i duhanskog otpada (b) 

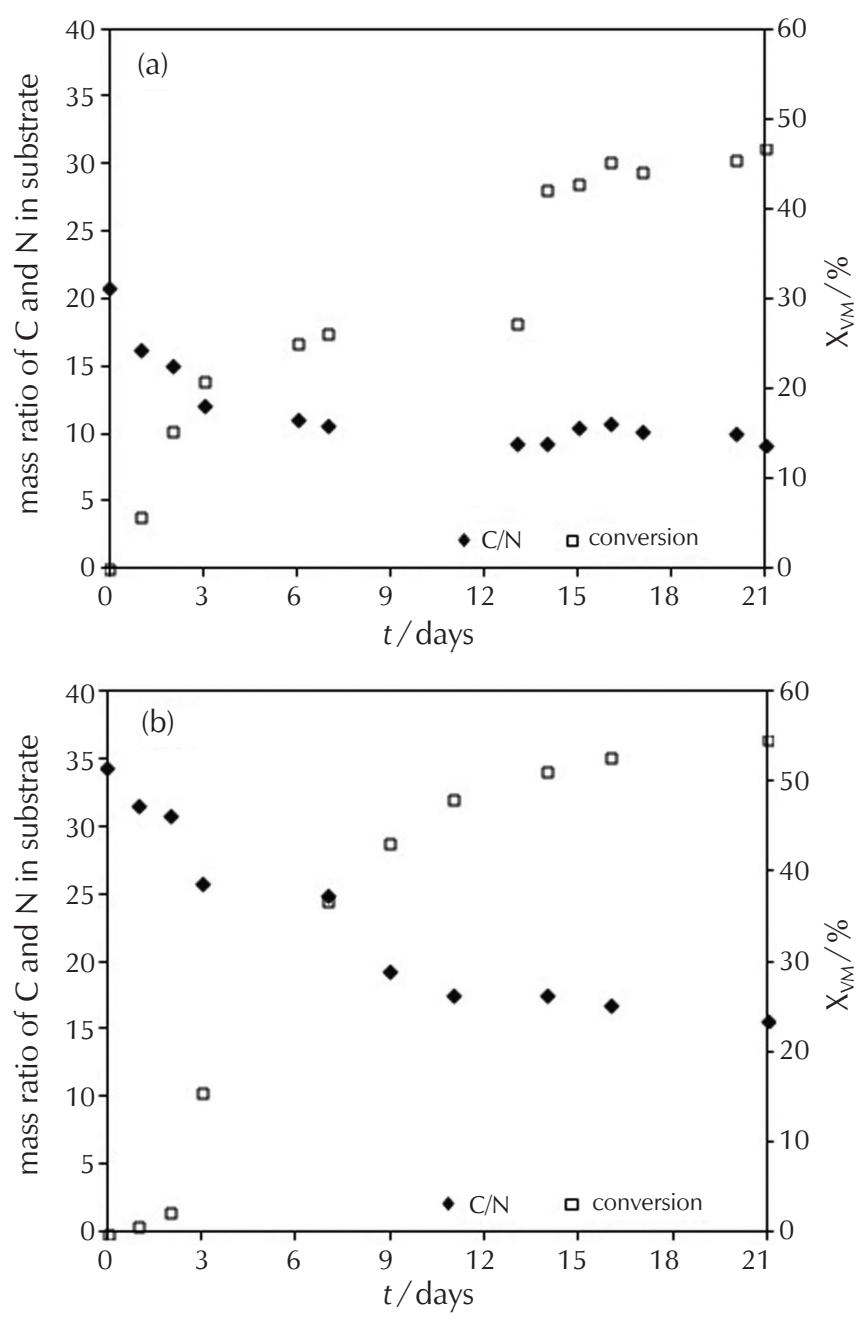

Fig. $7-\mathrm{C} / \mathrm{N}$ mass ratio and conversion of tobacco waste (a) and grape and tobacco waste (b) during 21 days of composting process

Slika 7 - Promjena masenog omjera C/N i konverzije tijekom 21 dana kompostiranja duhanskog otpada (a) i mješavine duhanskog otpada i otpada od grožđa (b)

\section{Conclusions}

During 21 days of composting tobacco waste and a mixture of tobacco and grape waste in a closed reactor, the following was recorded. Initial pH of compost of tobacco waste and mixture of tobacco and grape waste was 6.5 and 5.3, respectively. Initial $\mathrm{C} / \mathrm{N}$ mass ratio was 21 and 35 , and at the end of the composting process 10 and 23, respectively, which shows degradation of organic matter in both experiments. Temperature, $\mathrm{pH}$ and $\mathrm{C} / \mathrm{N}$ mass ratio influenced the emission of $\mathrm{CO}_{2}$ and $\mathrm{NH}_{3}$. Most of the carbon dioxide evolved during the first 10 days of the composting process due to the highest activity of microorganisms. The cumulative evolved $\mathrm{CO}_{2}$ in volatile matter during 21 days of composting of tobacco waste and mixture of tobacco and grape waste was $94.01 \mathrm{~g} \mathrm{~kg}^{-1}$ and $208.18 \mathrm{~g} \mathrm{~kg}^{-1}$, respectively. From the given values of evolved $\mathrm{CO}_{2}$ in TG and TGW experiment, it can be concluded that a higher biodegradation rate was achieved in the experiment with TGW, which is in accordance with the obtained higher conversion in the TGW experiment at the end of the process. At the beginning of the composting process, the concentration of volatile ammonia was low, and then increased with increasing $\mathrm{pH}$ value $(\mathrm{pH}=9)$ of composting mass. The $\mathrm{cu}-$ mulative evolved $\mathrm{NH}_{3}$ in volatile matter during 21 days of composting of tobacco waste and mixture of tobacco and grape waste was $504.81 \mathrm{mg} \mathrm{kg}^{-1}$ and $122.456 \mathrm{mg} \mathrm{kg}^{-1}$, respectively, which shows that less ammonia had evolved in experiments with TGW where $\mathrm{C} / \mathrm{N}$ ratio was higher. From the obtained results, it can be concluded that the experiment TGW is better for composting than TW. TW has low $\mathrm{C} / \mathrm{N}$ ratio and more ammonia is evolved, and also contains nicotine which is toxic to microorganisms and lower conversion is achieved. After two weeks of composting TGW, the conversion had not changed, and temperature dropped to mesophilic phase and stayed in this phase until the end of the process, indicating that the third phase of the composting process was over and the maturation phase had started. In the maturation phase, the compost material needs to tumble and there is no need for aeration.

\section{List of abbreviations and symbols Popis kratica i simbola}

\begin{tabular}{|c|c|}
\hline CFU & $\begin{array}{l}\text { - colony forming units } \\
\text { - ukupan broj živih stanica }\end{array}$ \\
\hline DM & $\begin{array}{l}\text { - dry matter } \\
\text { - suha tvar }\end{array}$ \\
\hline TGW & $\begin{array}{l}\text { - mixture of tobacco and grape waste } \\
\text { - mješavina duhanskog otpada i otpada od grožđa }\end{array}$ \\
\hline TW & $\begin{array}{l}\text { - tobacco waste } \\
\text { - duhanski otpad }\end{array}$ \\
\hline VM & $\begin{array}{l}\text { - volatile matter } \\
\text { - hlapljiva tvar }\end{array}$ \\
\hline$t$ & $\begin{array}{l}\text { - time, d } \\
\text { - vrijeme, d }\end{array}$ \\
\hline$X$ & $\begin{array}{l}\text { - degree of reaction, } \% \\
\text { - stupanj reakcije, \% }\end{array}$ \\
\hline$w$ & $\begin{array}{l}\text { - mass fraction, } \%, \mathrm{gkg}^{-1}, \mathrm{mg} \mathrm{kg}^{-1} \\
\text { - maseni udjel, \%, } \mathrm{gkg}^{-1}, \mathrm{mg} \mathrm{kg}^{-1}\end{array}$ \\
\hline$\gamma$ & $\begin{array}{l}\text { - mass concentration, } \mathrm{mgdm}^{-3} \\
\text { - masena koncentracija, } \mathrm{mgdm}^{-3}\end{array}$ \\
\hline$\theta$ & $\begin{array}{l}\text { - Celsius temperature, }{ }^{\circ} \mathrm{C} \\
\text { - Celsiusova temperatura, }{ }^{\circ} \mathrm{C}\end{array}$ \\
\hline
\end{tabular}




\section{References \\ Literatura}

1. N. Saithep, S. Dheeranupatana, P. Sumrit, S. Jeerat, S. Boonchalearmkit, J. Wongsanoon, C. Jatisatienr, Composting of tobacco plant waste by manual turning and forced and forced aeration system, Maejo International Journal of Science and Technology 3 (2009) 248-260.

2. N. Bertran, X. Sort, M. Soliva, I. Trillas, Composting winery waste: Sludges and grape stalks, Bioresource Technol. 95 (2004) 203-208, doi: https://doi.org/10.1016/j.biortech.2003.07.012.

3. J. Ferrer, G. Paez, Z. Marmol, E. Ramones, C. Chandler, M. Marin, A. Ferrer, Agronomic use of biotechnologically processed grape waste, Bioresource Technol. 76 (2001) 39-44, doi: https://doi.org/10.1016/S0960-8524(00)00076-6.

4. M. Benito, A. Masaguer, A. Moliner, C. G. Cogger, A. I. Bary, Comparison of a gas detection tubes test with the traditional alkaline trap method to evaluate compost stability, Biol. Fert. Soils 41 (2005) 447-450, doi: https://doi.org/10.1007/ s00374-005-0848-5.

5. T. J. Hu, G. M. Zeng, D. L. Huang, H. Y. Yu, X. Y. Jiang, F. Dai, G. H. Huang, Use of potassium dihydrogen phosphate and sawdust as adsorbents of ammonical nitrogen in aerobic composting process, J. Hazard. Mater. 141 (2007) 736-744, doi: https://doi.org/10.1016/j.jhazmat.2006.07.027.

6. N. Xue, Q. Wang, C. Wu, L. Zhang, W. Xie, Enhanced removal of $\mathrm{NH}_{3}$ during composting by a biotrickling filter inoculated with nitrifying bacteria, Biochem. Eng. J. 51 (2010) 86-93, doi: https://doi.org/10.1016/j.bej.2010.05.007.

7. E. Pagans, X. Font, A. Sanchez, Biofiltration for ammonia removal from composting exhaust gases, Chem. Eng. J. 113 (2005) 105-110, doi: https://doi.org/10.1016/j. cej.2005.03.004.

8. E. Pagans, R. Barrena, X. Font, A. Sanchez, Ammonia emissions from the composting of different organic wastes: Dependency on process temperature, Chemosphere 62 (2006) 1534-1542, doi: https://doi.org/10.1016/j. chemosphere.2005.06.044.

9. K. Nakasaki, A. Ohtaki, H. B. Takano, Biodegradable plastic reduces ammonia emission during composting, Polym. Degrad. Stabil. 70 (2000) 185-188, doi: https://doi. org/10.1016/S0141-3910(00)00104-X.

10. J. M. Paillat, P. Robin, M. Hassouna, P. Leterme, Predicting ammonia and carbon dioxide emissions from carbon and nitrogen biodegradability during animal waste composting, Atmos. Environ. 39 (2005) 6833-6842, doi: https://doi. org/10.1016/j.atmosenv.2005.07.045.

11. T. Jiang, F. Schuchardt, G. Li, R. Guo, Y. Zhao, Effect on C/N ratio, aeration rate and moisture content on ammonia and greenhouse gas emission during the composting, J. Environ. Sci. 23 (2011) 1754-1760, doi: https://doi.org/10.1016/ S1001-0742(10)60591-8.

12. Y. K. Jeong, S. J Hwang, Optimum doses of $M g$ and $P$ salts for precipitating ammonia into struvite crystals in aerobic com- posting, Bioresource Technol. 96 (2005) 1-6, doi: https:// doi.org/10.1016/j.biortech.2004.05.028.

13. ÖNORM S 2023, Analytical Methods and Quality Control for Waste Compost, Austrian Standards Institute, Vienna, 1986.

14. T. Osada, K. Kuroda, M. Yonaga, Determination of nitrous oxide, methane, and ammonia emissions from a swine waste composting process, J. Mater. Cycles Waste 2 (2000) 51-56.

15. I. M. Kolthoff, E. B. Sandel, Inorganic quantitative analysis (in Croatian), Školska knjiga (1951) Zagreb, 347-352.

16. F. Briški, M. Vuković, K. Papa, Z. Comzi, T. Domanovac, Modelling of composting of food waste in a column reactor, Chem. Pap. 61 (2007) 24-29, doi: https://doi.org/10.2478/ s11696-006-0090-0.

17. A. D. Neklyudov, G. N. Fedotov, A. N. Ivankin, Aerobic Processing of Organic Waste into Composts, Appl. Biochem. Micro. 42 (2006) 341-353, doi: https://doi.org/10.1134/ S0003683806040016.

18. J. Venglovsky, N. Sasakova, M. Vargova, Z. Pacajova, I. Placha, M. Petrovsky, D. Harichova, Evolution of temperature and chemical parameters during composting of the pig slurry solid fraction amended with natural zeolite, Bioresource Technol. 96 (2005) 181-189, doi: https://doi.org/10.1016/j. biortech.2004.05.006.

19. Y. Liang, J. J. Leonard, J. J. R. Feddes, W. B. Mcgill, Influence of carbon and buffer amendment on ammonia volatilization in composting, Bioresource Technol. 97 (2003) 748-761, doi: https://doi.org/10.1016/j.biortech.2005.03.041.

20. F. Briški, Z. Gomzi, A. Hublin, M. Vuković, Aerobno kompostiranje otpadaka voća i povrća: modeliranje procesa, Kem. ind. 52 (2003) 95-102.

21. C. Sundberg, S. Smars, H. Jonsson, Low pH as an Inhibiting Factor in the Transition of Mesophilic and Thermophilic Phase in Composting, Bioresource Technol. 95 (2004) 145150, doi: https://doi.org/10.1016/j.biortech.2004.01.016.

22. R. T. Haug, The Practical Handbook of Compost Engineering, Chapter 9., Lewis Publishers, United States of America, (1993) 326-327.

23. B. Beck-Friis, S. Smars, H. Jonsson, H. Kirchmann, Gaseous Emissions of Carbon Dioxide, Ammonia and Nitrous Oxide from Organic Household Waste in a Compost Reactor under Different Temperature Regimes, J. Agr. Eng. Res. 78 (2001) 423-430, doi: https://doi.org/10.1006/jaer.2000.0662.

24. S. H. Kwon, D. H. Lee, Evaluation of Korean food waste composting with fed-batch operations II: using properties of exhaust gas condensate, Process Biochem. 39 (2004) 10471055, doi: https://doi.org/10.1016/S0032-9592(03)002309.

25. M. P. Bernal, C. Paredes, M. A. Sanchez-Monedero, J. Cegarra, Maturity and stability parameters of composts prepared with a wide range of organic wastes, Bioresource Technol. 63 (1998) 91-99, doi: https://doi.org/10.1016/S09608524(97)00084-9. 


\section{SAŽETAK \\ Emisija plinova tijekom kompostiranja čvrstog otpada \\ Dajana Kučić* i Felicita Briški}

Kompostiranje je proces biorazgradnje organske tvari u stabilan produkt - kompost, pri čemu se oslobađa toplina, voda, $\mathrm{CO}_{2}$ i $\mathrm{NH}_{3}$. Svrha ovog rada bila je odrediti količinu nastalih izlaznih plinova, $\mathrm{CO}_{2}$ i NH $\mathrm{NH}_{3}$, tijekom kompostiranja duhanskog otpada i mješavine otpada duhana i grožđa. Tijekom 21 dana kompostiranja duhanskog te miješanog duhanskog i grožđanog otpada, prema ukupnim hlapljivim tvarima, nastalo je 94,01 $\mathrm{g} \mathrm{kg}^{-1}$ i $208,18 \mathrm{~g} \mathrm{~kg}^{-1}$ ugljikova dioksida, odnosno $504,81 \mathrm{mg} \mathrm{kg}^{-1}$ i 122,45 $\mathrm{mg} \mathrm{kg}^{-1}$ amonijaka.

\section{Ključne riječi}

Kompostiranje, agroindustrijski otpad, adijabatski zatvoreni sustav, emisija amonijaka, emisija ugljikova dioksida

Fakultet kemijskog inženjerstva i tehnologije

Izvorni znanstveni rad Sveučilište u Zagrebu

Zavod za industrijsku ekologiju

Prispjelo 9. prosinca2016

Marulićev trg 19 Prihvaćeno 20. veljače 2017.

10000 Zagreb 